UDC: 371.12:811

\title{
LANGUAGE COMPETENCE OF A FOREIGN LANGUAGE TEACHER: A STEP TOWARDS DEFINITION
}

\author{
NATALIYA SOKOLOVA ${ }^{1}$ \\ University of Edinburgh, \\ Moray House School of Education, \\ Edinburgh, UK
}

Tema ovog članka je usavršavanje jezika nastavnika koji predaju strani jezik, a fokus je na konceptu profesionalne kompetencije nastavnika. Nijedna publikacija nije detaljno razjasnila šta tačno treba da uključi kompetencija nastavnika stranog jezika. Pokušaj definisanja ovakve kompetencije odmah vodi ka različitim i ponekad suprotstavljenim stavovima o tome šta nastavnik stranog jezika treba da poseduje. Koristeći tu činjenicu kao polaznu tačku pokušaću da pružim svoj stav o jezičkoj kompetenciji nastavnika stranog jezika i ključnim elementima koji je sačinjavaju. Polazna hipoteza ovog rada je da pored „opšteg jezika” i svesti o jeziku, nastavnik stranog jezika treba da ima razvijene komunikativne veštine, kako u učionici, tako i van nje. U prilog ovakvom stavu ponudiću jedan preliminarni, šematski opis jezičke kompetencije nastavnika stranog jezika, što smatram samo prvim korakom pri definisanju jezičke kompetencije nastavnika stranog jezika.

Ključne reči: usavršavanje nastavnika stranog jezika, neizvorni govornik kao nastavnik stranog jezika, jezička kompetencija, engleski, veštine nastavnika stranog jezika.

\section{INTRODUCTION}

This paper deals with the issue of teacher professional competence, namely, target language competence of a foreign language (FL) teacher. Although the definition of teacher competence seems to be clear and, in some respect, obvious, the question is far from being solved and teacher language competence is far from being defined. A clear and precise definition of language competence of a $\mathrm{FL}$ teacher may contribute to reconsidering and re-shaping of content and outcomes of language teacher training

1 Kontakt podaci (Email): N.Sokolova@sms.ed.ac.uk 
programmes (with many of them still treating teacher language competence as 'general') together with content and format of language assessment and evaluation of language teachers at both pre-service and in-service levels.

The purpose of this article is to demonstrate complexity of the concept 'language competence of a FL teacher' and variety of factors influencing its content. Doing review of publications in the area is similar to doing a jigsaw puzzle - there are a lot of pieces but the picture itself is quite difficult to create. Therefore, I start with reviewing books, articles and research projects on language teacher language development which, in its turn, generates my own view of a model of FL teacher language competence. I then describe empirical steps yet to be done for a tentative model of teacher language competence to be thoroughly described.

\section{FOREIGN LANGUAGE TEACHER LANGUAGE COMPETENCE: THEORETICAL CONSIDERATIONS}

Aims of professional development are considered to be one of core elements in any teacher training programme. Nowadays aims are usually described in terms of competences which are presented through knowledge, skills and attitudes.

Despite the fact that much has been written about FL teacher training and development, there is a considerable gap in TESOL and TEFL literature as far as a language teacher's language competence is concerned though several publications have been traced in this field (Thomas 1987; Wright 1993; Trappes-Lomax 2002; Widdowson 2002; Richards 2010):

There is a gap between books about language (for students, teachers, linguists) which do not deal specifically with teacher education and books about teacher education which do not deal with language. (Trappes-Lomax 2002: 1)

The authors consider the language (grammar, vocabulary, communication skills, etc.) a foreign language teacher needs and, directly or indirectly, state that English of an English language teacher is different from English of people of other occupations in terms of amount of knowledge about language, range of language skills, degree of accuracy and fluency of oral and written performance.

Thomas (1987: 34) was the first to introduce the definition of 'language teacher competence' as 'competence to impart competence on learners'. Thomas (1987: 37) singled out three components of language teacher competence:

- Competence in language teaching, i.e. pedagogic competence

- Explicit knowledge of language system and use - language awareness

- Competence in language system and use - language competence:

- 'formal' component (phonological, graphological, syntactical, lexical)

- contextual/discourse component

- stylistic component

- informational appropriacy (theme and rheme, anaphora, etc.) 
According to Thomas (1987: 37), pedagogical competence comprises four components - management, teaching, preparation and assessment - with 'all these presupposing language competence', i.e. Classroom English, speaking skills, lesson planning and materials development skills. Thus, Thomas was the first to conclude that language competence of a FL teacher is wider and more complex in comparison to that of a general language user; teacher language competence is interrelated with pedagogical competence. Still, many issues remain unresolved.

The idea of teacher language competence being wider than general language competence was further developed in the work of Wright and Bolitho (1993), Wright (2002) and Widdowson (2002). Wright and Bolitho (1993) view a language teacher as a language user, a language analyst and a language teacher. They define language awareness as 'awareness of how language works' and state it is crucial in accomplishing various tasks - preparing lessons, evaluating, adapting and writing materials, testing and assessing learners (Wright and Bolitho 1993: 292). Stating importance of language awareness, Wright and Bolitho do not, however, give any explanation or illustration of its components - knowledge or skills - which teachers must develop. Still, this work clearly demonstrates that language awareness should be an essential aim of FL teacher development and, therefore, assessment.

Wright (2002) states that successful language teaching requires proficiency in language use, knowledge of language and knowledge of teaching methods, which are in many cases interdependent and result in language awareness, or linguistic and pedagogic sensitivity to the problems of students. Besides, Wright (2002: 113) states that language awareness can be viewed as a part of teacher language proficiency, though the definition of proficiency 'is not so straightforward'. Similar to Wright, TrappesLomax (2002) thinks of involving both communicative proficiency and consciousness of language into language teacher education programmes.

A very important step was taken by Richards (2010: 110) who came out with a list of communicative skills a language teacher is expected to demonstrate in the target language:

- $\quad$ to comprehend texts accurately;

- $\quad$ to provide good language models;

- $\quad$ to maintain use of the target language in the classroom;

- $\quad$ to give explanations and instructions in the target language;

- to provide examples of words and grammatical structures, give accurate explanations;

- to use appropriate classroom language;

- to select target language resources;

- to monitor his/her own speech and writing for accuracy;

- to give correct feedback on learner language;

- to provide input at an appropriate level of difficulty;

- to provide language enrichment experience for learners'.

Thus, Richards' is first attempt to classify skills in accordance with ListeningReading-Speaking-Writing division and to single out the professional component which 
makes teacher skills different from the skills of language users and people of other occupations. Richards (2010: 110-112) suggests that the skills are expected to manifest themselves mostly at the classroom level, though there is an extension to out-of-classroom use which is viewed as lesson preparation. Richards' list may be considered a good basis for further development of teacher language skill taxonomy with some points being classified and explained. For example, for text comprehension, there is no indication on text types, topics, length and whether the texts are written (reading) or oral (listening).

Further literature search revealed some limited advice about language teacher development programmes from preparing teachers for "linguistic emergency" (Marton 1988: 99) to "developing study skills (listening to lectures, contributing at seminars, writing essays) and skills that the teacher will need after the course" (Kennedy 1983: 76) and enhancing the role of the language development component in teacher standards (Barnes 2002: 199).

Another area for analysis which stands a bit apart from the previously reviewed sources due to its completely practice-oriented nature is language coursebooks for language teachers. The literature search in this area resulted in identifying two books for language teachers which aim at FL teacher language competence development (Spratt 1996; Thornbury 1997).

Thornbury's About Language was reviewed with the purpose to see if he considers some specific kind of language awareness a language teacher should demonstrate or it may be treated as 'general' language awareness. It seems that the content of the units - phonological and grammatical aspects - does not make it different from a 'general English' course. Similar content is prescribed by Common European Framework (1996, 2001) and can be found in language coursebooks and, therefore no differentiation is made between 'general grammar' and 'teacher grammar'.

There is another dimension though - the way the linguistic content is presented, i.e. the tasks, including materials evaluation and lesson planning. Judging by the way Thornbury presents language items he definitely aims at combining knowledge about language with pedagogical knowledge of a language teacher. In addition, Thornbury discusses pedagogical consequences of limited linguistic knowledge. Judging by these, it is not the language load itself which is different for a language teacher (in comparison to general language awareness) but the way it is applied in the classroom.

Spratt (1996) takes a wider look at FL teacher language competence. As the book title English for the teacher suggests, she is considering both teacher language awareness and communicative skills - listening, speaking, reading, writing together with 'teacher-specific' vocabulary areas, ELT terminology and Classroom English. As a result, in addition to a clearly defined bulk of ELT terminology a FL teacher is supposed to master, Spratt singles out essential language skills, text and task types a FL teacher deals with on a routine basis.

The idea of $\mathrm{FL}$ teacher language has also received some attention through research projects within the last twenty years. Though the projects differ in scope, research methods and findings, they all cast some light on what a language teacher's language competence might include. They definitely add some empirical data to theoretical findings published in few books and articles. 


\begin{tabular}{|c|c|c|c|c|c|}
\hline & Methods & Level & Population & Findings & $\begin{array}{l}\text { Countries } \\
\text { involved }\end{array}$ \\
\hline 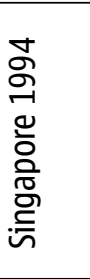 & \begin{tabular}{|l|} 
- survey \\
- observation
\end{tabular} & 岕芯 & $\begin{array}{l}\text { primary school } \\
\text { teachers of English } \\
\text { as a FL }\end{array}$ & $\begin{array}{l}3 \text { areas singled out: } \\
\text { - language for } \\
\text { information } \\
\text { - language for } \\
\text { teaching } \\
\text { - language } \\
\text { appreciation }\end{array}$ & Singapore \\
\hline 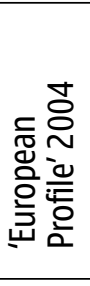 & $\begin{array}{l}\text { - literature } \\
\text { and } \\
\text { document } \\
\text { review } \\
\text { - case study } \\
\text { - interviews }\end{array}$ & 岂岂 & $\begin{array}{l}\text { staff of European } \\
\text { colleges and } \\
\text { universities } \\
\text { involved in teacher } \\
\text { development }\end{array}$ & $\begin{array}{l}\text { a framework for } \\
\text { teacher development } \\
\text { curriculum design } \\
\text { and evaluation }\end{array}$ & $\begin{array}{l}\text { Austria, UK } \\
\text { Germany } \\
\text { Spain } \\
\text { Finland } \\
\text { Latvia } \\
\text { Norway } \\
\text { Italy, Poland }\end{array}$ \\
\hline 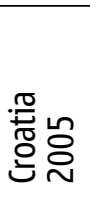 & $\begin{array}{l}\text { - essay } \\
\text { analysis } \\
\text { - ranking }\end{array}$ & 岂岂 & $\begin{array}{l}\text { students of English } \\
\text { language and } \\
\text { literature }\end{array}$ & $\begin{array}{l}\text { professional skills a FL } \\
\text { teacher needs (mostly } \\
\text { speaking) }\end{array}$ & Croatia \\
\hline 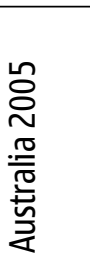 & $\begin{array}{l}\text { - literature } \\
\text { review } \\
\text { - teacher } \\
\text { interviews } \\
\text { - survey }\end{array}$ & 岕岕 & $\begin{array}{l}\text { teachers of } \\
\text { Indonesian as a FL } \\
\text { in Australia }\end{array}$ & $\begin{array}{l}\text { a FL teacher's } \\
\text { communicative } \\
\text { competence } \\
\text { described } \\
\text { - general language } \\
\text { - classroom-related } \\
\text { language }\end{array}$ & Australia \\
\hline 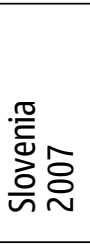 & $\begin{array}{l}\text { - literature } \\
\text { review } \\
\text { - survey } \\
\text { - lesson } \\
\text { observation }\end{array}$ & 岕芯 & $\begin{array}{l}\text { Teachers of } \\
\text { English with } \\
\text { different levels of } \\
\text { experience (1 and } \\
\text { more years) }\end{array}$ & $\begin{array}{l}\text { Classroom English } \\
\text { analyzed in terms of } \\
\text { skills } \\
\text { Skills prioritized: } \\
\text { Speaking, Reading, } \\
\text { Writing, Listening }\end{array}$ & Slovenia \\
\hline
\end{tabular}

Table 1: Language for the teacher projects summary

Narrowing the search down from language development of FL teachers to their assessment (which presupposes teacher language competence defined) results in only a few articles (Grant 1997; Elder 1994, 2001) published on language assessment issues in language teacher development. Grant and Elder both emphasize that the model of language teacher language competence needs further research and development.

Grant suggests using the model of Communicative Language Ability (Bachman 1990) as a basis for teacher language competence description, Elder (2001: 154) comes out with specific language skills required for teaching purposes:

- command of subject-specific/metalinguistic terminology;

- discourse competence required for classroom delivery of subject content, i.e. 
command of linguistic features (directive, questioning, rhetorical signaling devices, simplification strategies, etc.).

The examinations for language teachers reviewed by these authors - the Spanish test for bilingual teacher certification in Arizona (Grant 1997) and Language Proficiency test for teachers (LPTT) of Italian and Japanese (Elder 2001) - aim at assessing FL teacher language communicative skills in listening, reading, writing and speaking with a special emphasis laid on Classroom Language (Elder 2001), interaction with parents (Grant 1997) and teacher ability to use the target language as a medium of instruction including the ability 'to produce well-formed input' and 'to draw learners' attention to the formal features of the target language' (Elder 2001).

\subsection{THEORETICAL CONSIDERATIONS OF FOREIGN LANGUAGE TEACHER LANGUAGE COMPETENCE: TENTATIVE CONCLUSIONS}

There is no commonly accepted description of language competence one can refer to. The term 'language teacher competence' seems to fall into the category of words that are widely used without a precise meaning. It may be explained by the complexity of the term and its high context dependence (different school types, different 'traditions' of using the target language in the classroom, different access to teaching materials, etc.).

Elements of language teacher language competence are described by several authors and projects with a different degree of theoretical and empirical detail. No principal contradiction is observed in what authors say about the competence in question, though there are some differencesin terminology. The majority of publications state that a FL teacher is expected to demonstrate:

- $\quad$ teacher language awareness, which is different from language awareness of other occupations or that of general language users in terms of its interrelationship with pedagogical knowledge, and results in an ability to teach language to different groups of students;

- all four language skills (listening, speaking, reading, writing) to be employed in the classroom, for lesson preparation, materials development and other professional purposes. There is no direct indication on the priority of some skills, though many research projects emphasize the importance of speaking, with reading and writing following it;

- ' 'teacher speaking', most often referred to as Classroom Language. This is the area which received much attention in the 1980s through both theoretical and empirical studies (Hughes 1987; Willis 1987). It resulted in Classroom Language quite carefully described with classroom vocabulary, grammar, functions and discourse features identified.

Scarce publications about language assessment for $\mathrm{FL}$ teachers, in a similar vein, emphasize the importance of all four skills and raise the issue of language competence of a language teacher agreeing with a general model of language competence. Grant (1997) suggests sticking to Bachman's (1990) model of communicative language ability, 
more recent publications (e.g. Sešek 2007) employ the terminology and approach of the Common European Framework (2001) which, despite some drawbacks, remains the most thorough description of language competence and levels language users achieve. Thus, in this article language competence of a $\mathrm{FL}$ teacher is viewed as shown in Picture 2. The components of language competence to a great degree 'affected' by the language teaching profession are shown in grey.

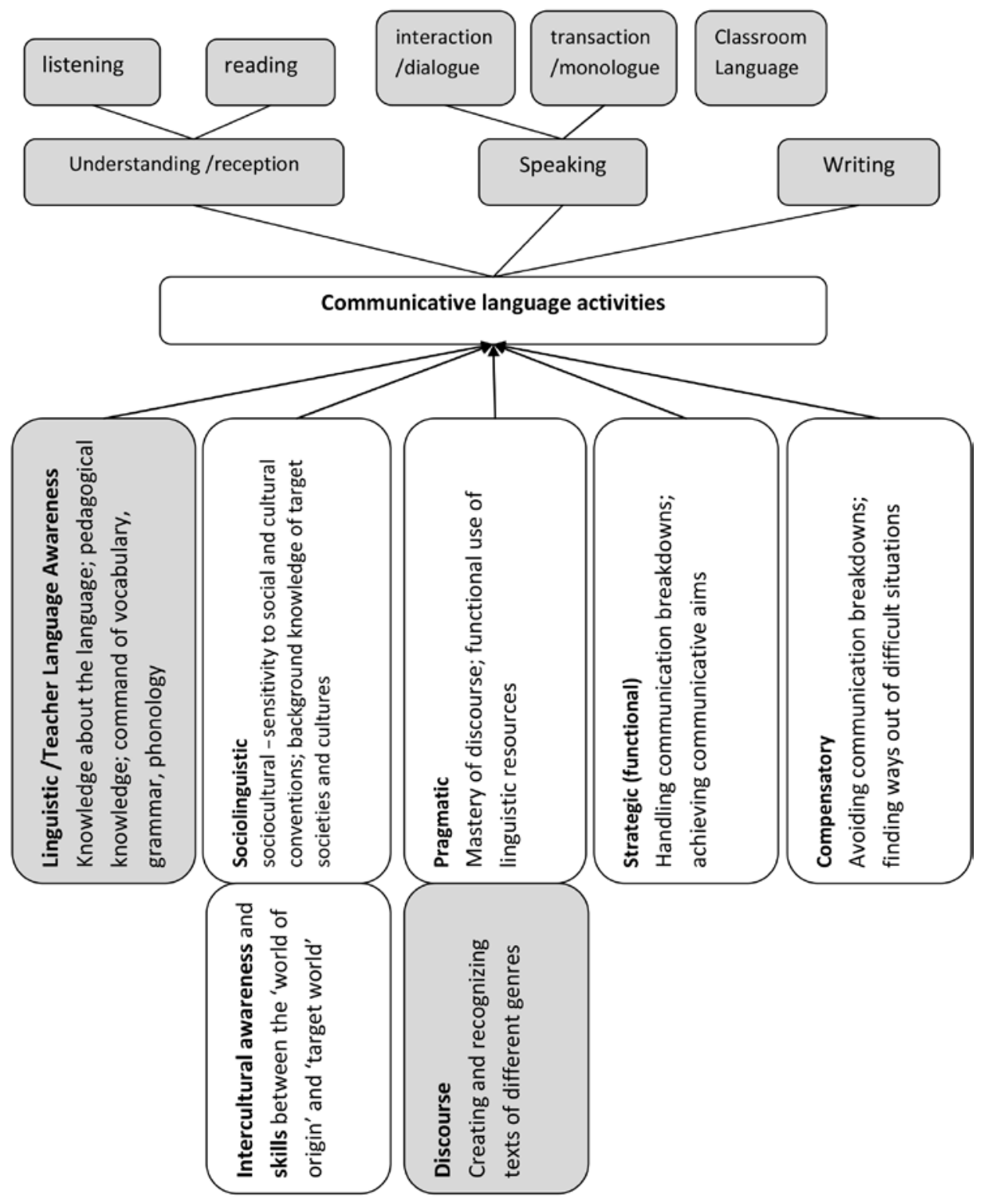

Graph 1: FL teacher language competence (based on (EF 2001) 


\section{FURTHER RESEARCH METHODOLOGY}

Review of publications is considered the first and very important step in describing FL teacher language competence as it provides an essential theoretical background. Nevertheless, the research cannot be treated as complete without empirical data which is being obtained from various sources ${ }^{2}$ :

1. Through analysis of documents in thearea of foreign language teacher development in different countries (UK, USA, Australia, Poland, Russia, Slovenia, Hong Kong):

- National curricula for language teacher development

- Syllabi and sample papers for national examinations for FL teachers (Australia, Brazil, Hong Kong, USA)

- International language examinations for teachers of English: PRAXIS ${ }^{\circledR}$ (Educational Testing Service, USA); TKT ${ }^{\circledR}$, ICELT, DELTA (Cambridge ESOL, UK)

The analysis will result in professional language skills, topical areas, text and task types a FL teacher deals with identified as shown in samples (Table 2, 3) which complement 'general' language skills presented in the Common European Framework of Reference (2001).

\begin{tabular}{|c|c|}
\hline $\begin{array}{l}\text { Listening } \\
\text { general } \\
\text { (CEF 2001: } \\
65-66) \text {. }\end{array}$ & $\begin{array}{l}\text { - } \quad \text { listening to public announcements (information, instructions, } \\
\text { warnings, etc.); } \\
\text { - } \quad \text { listening to media (TV, radio, recordings, cinema); } \\
\text { - } \quad \text { listening as a member of live audience (theatre, meetings, public } \\
\text { lectures, entertainment); } \\
\text { - } \quad \text { listening to conversations (with/without taking part in them) }\end{array}$ \\
\hline Professional & $\begin{array}{ll}\text { - } & \text { listening to colleagues in formal and informal discussions; } \\
\text { - } & \text { listening to speakers at lectures, conferences, seminars with/without } \\
& \text { visual support; } \\
\text { - } & \text { listening to students (for error correction and feedback); } \\
\text { - } & \text { listening and responding to student talk; } \\
\text { - } & \text { listening to ELT materials (for lesson preparation). }\end{array}$ \\
\hline
\end{tabular}

Table 2. Language skills of a FL teacher (sample; skills not shown in the order of priority)

\begin{tabular}{|l|l|}
\hline $\begin{array}{l}\text { Listening } \\
\text { general } \\
\text { (personal) (CEF } \\
\text { 2001: 95) }\end{array}$ & $\begin{array}{l}\text { public announcements, instructions, public speeches, lectures, } \\
\text { presentations, formal ceremonies, entertainment (drama, shows, songs, } \\
\text { audiobooks), spot commentaries, news, public debates, dialogues and } \\
\text { conversations, job interviews }\end{array}$ \\
\hline professional & $\begin{array}{l}\text { lectures, presentations (at seminars, webinars, etc.), student talk, } \\
\text { coursebook audio-/videosupport, audiomaterials for teaching purposes }\end{array}$ \\
\hline
\end{tabular}

Table 3. Text types a FL teacher deals with (sample; texts not shown in the order of priority)

2 Empirical research is already in progress but will not have been complete at the time of the article submission. 
2. Through needs analysis of English teachers (and teachers of other foreign languages in a long-term perspective). Needs analysis that is being currently performed through survey includes dialogues with teachers of English in Russia (with a plan to involve teachers from other countries). The survey aims at getting data on tasks performed by teachers and their frequency; communicative skills teachers require with top skills identified; text types teachers deal with.

It is hoped that empirical data obtained will add to data presented by other researchers and collected with different research instruments (e.g. LPATE Project (Hong Kong 2001); Teacher Competence project (Croatia 2005); Sešek 2007) - mostly classroom observation and interviews with FL teachers. The taxonomy of language skills, text and task types, a list of essential 'teacher' vocabulary and description of teacher language awareness would complement a theoretical model of $\mathrm{FL}$ teacher language competence to make it clear and transparent for everybody involved in pre- and in-service language teacher education.

\section{CONCLUSION}

In this paper I have tried to show the complexity of FL teacher language competence and diversity of its elements. I propose that language competence of a FL teacher comprises teacher language awareness, four communicative skills (listening, reading, speaking, writing) for in- and out-of-classroom communication, including Classroom Language; teacher-specific vocabulary with all of them complementing, but not substituting 'general' language knowledge and skills users are expected to demonstrate. I am aware of the fact that the components of the model presented in this article are intricately interconnected in practice and the separation is only possible for the purpose of research.

It is hoped the theoretical and empirical procedures described above will produce a multi-faceted analysis of language teacher language competence and its components which, in its turn, may contribute to:

- specifying aims of teacher language development in terms of skills, topical areas, vocabulary, teacher linguistic competence;

- reconsidering the focus of teacher linguistic development - from knowledge about the language to ability to teach language items;

- widening the range of tasks and texts in teacher language development courses.

Though some statements above might seem obvious for some teacher development institutions the facts obtained demonstrate general vagueness of teacher development aims which immediately results in a vague professional component of teacher language courses. 


\section{REFERENCES}

Common European Framework of Reference for Languages: Learning, Teaching, Assessment. 2001. Cambridge: Cambridge University Press.

Elder, C. 1994. Performance testing as benchmark for LOTE teacher education. Melbourne papers in language testing 3 (1), 1-25.

Elder, C. 2001. Assessing the language proficiency of teachers: are there any border controls? Language testing 18 (2), 149-170.

Grant, L. 1997. Testing the language proficiency of bilingual teachers: Arizona's Spanish proficiency test. Language testing 14 (1), 23-46.

Kennedy, C. 1983. An ESP approach to EFL/ESL teaacher training. The ESP Journal 2, 73-85.

Richards, J. C. 2010. Competence and performance in language teaching. RELC Journal $41,101-122$.

Sešek, U. 2007. English for teachers of EFL: toward a holistic approach. English for Specific Purposes 26, 411-425.

Spratt, M. 1996. English for the teacher: a language development course. Cambridge: CUP. Thomas, A. L. 1987. Language teacher competence and language teacher education. In R. Bowers (ed.) Language teacher education: an integrated programme for EFL teacher training. 0xford: Modern Language Publications in association with the British Council, 33-42.

Thornbury, S. 1997. About Language. Cambridge: CUP.

Trappes-Lomax, H. 2002. Language in language teacher education: a discourse perspective. In H. Trappes-Lomax (ed.) Language in language teacher education. Amsterdam/ Philadelphia: John Benjamins, 1-19.

Widdowson, H. G. 2002. Language teaching: defining the subject. In H. TrappesLomax (ed.) Language in language teacher education. Amsterdam/Philadelphia: John Benjamins, 67-81.

Wright, T. 2002. Doing language awareness. Issues for language study in language teacher education. In $\mathrm{H}$. Trappes-Lomax (ed.) Language in language teacher education. Amsterdam/ Philadelphia: John Benjamins, 113-130.

Wright, T. and R. Bolitho. 1993. Language awareness: a missing link in teacher education. ELT Journal 47 (4), 292-304.

\section{SUMMARY}

\section{LANGUAGE COMPETENCE OF A FOREIGN LANGUAGE TEACHER: A STEP TOWARDS DEFINITION}

This article is about language development of a foreign language (FL) teacher and is centred around the concept of teacher professional competence. Although the definition seems clear and indisputable, no publication has been traced that would clarify what a FL teacher language competence is. It immediately leads to diverse and sometimes contradictory views of content and language skills a FL teacher is supposed to demonstrate. I use this fact as a starting point and make an attempt to provide 
my view of a FL teacher language competence and essential elements that comprise it. My contention is that besides 'general language' and language awareness, a FL teacher should demonstrate skills in classroom and out-of-classroom communication. I support my view by coming out with a tentative and, at the moment, rather schematic description of FL teacher language competence. I consider this as the first step toward the definition of language teacher language competence to be followed by substantial empirical research which, hopefully, will contribute to a valid and more detailed description of the concept in question.

KEYWORDS: foreign language (FL) teacher development, non-native teachers of foreign languages, language competence, English, FL teacher skills.

(Review paper received 11.10.2011; revised 08.12.2012; accepted 17.12.2012) 